present provision for practical work is very inadequate, and the number of students has largely increased, while the required money is not forthcoming. I have already received the following donations, and shall gratefully acknowledge any further help :Mr. Charles Darwin, 5l. 55. ; Mr. Edward Dormer, 5l. ; Mr. T. Newland Allen, $3^{l}$. $3^{s}$; Mr. William Fasseridge, $2 l$. 2s. ; Anonymous, $2 l . ;$ Mr. Frank Dethridge, $1 l$. Is. ; Anonymous, 1l.; Mr. G. Eves, Il.; Mrs. Eves, $1 l$.; Mr. R. Wilkinson, Il. Is. ; Rev. C. T. Mayo, Il. Is. ; smaller subscriptions, 4l. I 5 s. Any further particulars will be most willingly given.

FLORENCE EvES, Science Student of Newnham College

Mitton House, Uxbridge, January 22

\section{Minerva Ornaments at Troy $v$. Net-Sinkers}

NoT having seen the numbers of NATURE regularly during the autumn, I did not observe Mr. Sayce's reply to my letter on the above subject until lately. I may perhaps trespass on your space with a few lines in reference to it.

I certainly did not observe any markings upon the stones in question that could be construed into any likeness to a buman face or to that of an owl. Not having the opportunity of reexamining them I must take this as granted according to Dr. Schliemann's judgment. Of course an expert can see, and see with certainty, what to one less exper:enced seems quite invisible. At the same time an enthusiast, as we all know, is rather apt to "oversee," and find in his relics more than actually exists. I say this, as it is a commen occurrence, and not in any way to disparage Dr. Schliemann's valuable work.

But admitting the existence of such outlines upon the stone; in question is it not far more probable that the half-savage natives of the Troad may have taken advantage of certain suggestive lines and roughly outlined an image upon a net-sinker, than that they made so large a number of rough and uncouth things as likenesses of Minerva? 1 he use of stones similarly chipped in the middle as net-sinkers seems common to savages all over the world, and it would seem to me therefore wiser to name them net-sinkers (with outlines, \&c.) than to ticket them "Minerva ornaments."

One point, if I understand him aright, which Dr. Schliemann endeavours to prove, is that Ancient Troy sto d close to the river. Hence the occurrence of net-sinkers may be considered as probable.

E. W. Claypole

Antioch College, Yellow Springs, O., December 18, I880

\section{THE PROVOST OF TRINITY COLLEGE,
DUBLIN}

THE Rev. Humphrey Lloyd, D.D., was born in 1800 . He was the eldest son of the Rev. Bartholomew Lloyd, who was Provost of Trinity College, Dublin, from 1831 to 1837 . Humphrey Lloyd entered his father's college in 1815, graduated as a Gold Medallist in Science in 1820 , and was elected a Fellow in 1824 . In I 83 I he was appointed Professor of Natural Philosophy. He was co-opted a Senior Fellow in 1843 , was made Vice-Provost in 1862 , and was appointed by warrant from the Crown to the Provostship in 1867 . He died, after a few days' illness, in the Provost's house on the I6th inst.

Full of years and honours, a very distinguished life has been brought to a close. Part of it was spent in laborious scientific research, part as the head of a great teaching establishment. Both portions of his life were a success, as even a short sketch of that life will show.

Lloyd was an excellent, though by no means a profound, mathematician. On becoming the Professor of Natural Philosophy he devoted himself with some ardour to the study of physical optics, and his report on this subject, laid before the fourth meeting of the British Association, was quite a masterpiece of reporting, and may still be consulted with pleasure. He was not however by any means content with having a knowledge of the work done by others, but was determined to enter on the field of original work himself; an opportunity soon offered. About ${ }^{8} 8_{32}$ Sir William Hamilton had been investigating the relations between the surface of waveslowness and that of the wave, and thereby had been led to the discovery of some new geometrical properties of the latter. These properties he demonstrated by means of certain transformations of the equations of the wavesurface, and he showed that this surface had four conoidal cusps at the extremities of the lines of single ray-velocity, at each of which the wave is touched not by two planes as Fresnel supposed, but by an infinite number forming a tangent cone of the second degree; while, at the extremities of the lines of single wave-velocity, there were four circles of plane contact, in every point of each of which the wave-surface is touched by a single plane. These singular properties led Hamilton to anticipate two new laws of refraction called by him external and internal "conical refraction." Hamilton was naturally desirous of having his theoretical conclusions proved by experiment; such experiments required a wonderful patience, delicacy of touch, and an almost instinctive sagacity. As possessing all these he selected Lloyd to solve his problem; and by his labours in a short time the reality of this interesting phenomenon was established.

The memoir by Hamilton and the experimental researches by Lloyd appear in the same volume (xvii.) of the Transactions of the Royal Irish Academy.

Lloyd published several treatises and memoirs relating to optical science, but he was persuaded by Sir Edward Sabine to turn his attention, about 1836 , to the subject of terrestrial magnetism. At his request the Board of Trinity College, Dublin, built a magnetical observatory, and the Professor entered with zeal upon those studies of magnetism which will for ever remain connected with his name. It would be unnecessary here to enumerate his very numerous writings on this subject.

In 1838 the British Association resolved that having regard to the high interest of the simultaneous magnetic observations which have been for some time carried on in Germany and various parts of Europe, and the important results to which these have led, they regard it as highly desirable that similar series of observations should be instituted in various parts of the British Dominions, and they suggested, as localities particularly important, Canada, Ceylon, St. Helena, Van Diemen's Land, and the Cape of Good Hope, also in the Southern Hemisphere. They further appointed as a Committee to approach the Government on this question Sir J. Herschel and Mr. Whewell, Dr. Peacock and Prof. Lloyd. The Committee, appointed late in August, at once set about their arduous work, and their memorial was laid before Lord Melbourne in the November following. The President and Council of the Royal Society strongly supported the memorial, and these concurrent representations were attended with full effect. In the Report of the Committee to the British Association in 1839 it is stated, "probably at the very moment when this report will be read, two ships, the Erebus and the Terror, under the command of Sir James Clark Ross, will be already on their voyage to the Antarctic Seas, carrying with them every instrument requisite for the complete and effectual prosecution of important magnetical researches in the high southern latitudes, and also complete establishments, both personal and instrumental, of the fixed magnetical observations to be placed at St. Helena, the Cape of Good Hope, and Van Diemen's Land. It was no wonder that the Committee were proud of the result of their labours, and that they acknowledged in strong terms the ample and liberal manner in which every demand on the national resources had been without exception granted, expressing at the same time the hope that this splendid example might be followed up by other nations. The report is signed J. F. W. Herschel and H. Lloyd.

In 1843 Dr. Lloyd pointed out a mode of reducing the error attending the determination of the intensity of the earth's magnetic force to less than one-fifth of that by the ordinary method.

In 1858 he again pointed out a fatal imperfection 
attending the ordinary mode of calculating the same force, and proposed instead a method requiring for its application only the use of the dip-circle, a vast advantage to the traveller, as it reduced to the smallest possible number the instruments which he would have to carry.

Along with his friend Sabine he visited the chief Continental cities in 1839, going as far as Berlin. This tour was altogether undertaken for the purposes of establishing still further a system of joint records of magnetical phenomena. His chief work in connection with magnetism was published under the title of "The Dublin Magnetical and Meteorological Observations" ( 2 vols. 4to, 1865-69). In 1857, when the British Association visited Dublin for a second time, Lloyd was their president, and many will still remember his dignified and courteous behaviour as such.

When, in 1867 , Dr. Lloyd was appointed provost, there was scarcely one dissentient voice. He had distinguished himself in his college career; his researches had reflected lustre on his university, and the belief in him was never shaken. During his period of office as Senior Fellow the study of the experimental sciences was introduced into the curriculum; in $185 \mathrm{I}$ it was even possibie to graduate as a Gold Medallist in these. To the experimental sciences were at first joined the natural sciences. During his provostship, these two groups were separated, to the great encouragement of the students in both. It was something wonderful to find how the now aged provost kept pace with the time, encouraging in every way the more modern view of things. Among the Professors and Fellows of his college he was very popular; he was always affable, while he possessed a quiet dignity. Proudly conscious of the position he held as Provost of Trinity College, he was singularly unambitious of worldly honours, but the honorary degree of D.C.L. from the sister University of Oxford, conferred on him in 1856 , was grateful to him, and he always spoke with pleasure of the recognition of his scientific merits by the Emperor of Germany, who conferred on him in .1874 the order "Pour le Mérite;" he was a F.R.SS. Lond. and Edin. He received the Cunningham gold medal of the Royal Irish Academy in 1862 .

\section{GEOLOGISING AT SHEPPEY}

SO much has been said about the abundance of fossil fruits at Sheppey that most geologists picture them lying plentifully upon the shore waiting to be picked up, and their only concern might well be at the outset to provide baskets strong and ample enough to convey their collectings home. A day spent $u_{2}$ on the beash would dispel these preconceived ideas.

The cliffs in a wet season are streams of liquid mud alternating with freshly-fallen landslips rendering them practically unapproachable. The wet and frost have this year proved exceptionally disastrous, and mere shreds of coast-paths remain. In places slabs of freshly-ploughed land are arrested half-way down the cliff, and at one point a cabbage-garden with the produce still only partly cut is streaming down to the beach. It is a good time for the cement works, but when Roman cement falls into disuse, as it seems likely to, then perhaps steps will be taken to stay this perpetual removal of fine arable land into the channels of the Thames. The beach itself is gravelly, and at low water there are extensive mud-flats. Among the gravel are patches of rolled pyrites, and among these pyrites the fruits are found, though valuable specimens are rare. This Christmas five experienced collectors, including Mr. W. H. Shrubsole, F.G.S., Mr. O. A. Shrubsole, F.G.S., Dr. Häusler, F.G.S., myself and brother, searched for several hours without a single fairly perfect fruit being found, and no greater success attended us on subsequent days. The vast bulk of the pyrites is amorphous; the majority of that which retains any recognisable shape is made up of twigs ; a consider able percentage is of nearly obliterated casts of shells ; and here and there are broken up Nipadites and other water-worn fragments of fruits. The best way to collect is to lie down upon the pyrites and examine it closely, when seeds and twigs that are passed over by the copperas-gatherers may be picked out. In this way I found seeds and scales of Araucaria, twigs of Ephedra, and many other shapes that may some day be recognised as parts of still-existing plants. No rest, short of doing absolutely nothing, could be more perfect to an overworked geologist's brain than to sprawl and smoke upon this beach.

The fruits themselves are so rare in the London Clay that they are seldom if ever found in situ, no prolific patches are known, and to attempt to dig for them would be futile. Their abundance in collections is due to the facts that for several miles there are lofty cliffs perpetually wasting away, and that the whole of the clay that reaches the beach is slowly removed in suspension by the sea, every particle of pyrites remaining behind until picked up for copperas or dissolved away. For two hundred years they have been known and searched for daily by the septaria and copperas collectors, and any one may quickly purchase an extensive collection. I have within a few months received from my friend Mr. Shrubsole enough Nipadites to fill a twenty-gallon cask, besides other fruits innumerable. Bowerbank's collection numbers many thousands, 300 specimens of a rare cone alone from Herne Bay having been in his possession. There is in the British Museum a MS. catalogue by a Mr. Crowe of Faversham, with $83 \mathrm{I}$ very rough drawings representing, as he supposed, 700 varieties. Ettingshausen, when he examined the British Museum collection, made 200 species. How many there may really be is still unknown, but the number doubtless is very considerably beyond the latter. Among the Coniferæ alone I have to add, besides the Ephedra, a Podocarpus near to $P$. elata, a Frenella almost indistinguishable from $F$. Endlicheri, and an Araucaria near $A$. Cunninghami. I have grave doubts about the correctness of the determination of all the other Coniferæ except a few of Bowerbank's Cupressineæ, and am still at work upon them. The state in which they are preserved is not sufficiently taken into account. The woody matter is generally preserved as lignite, and easily removed when rolled upon the beach, and the pyrites which remains filled the cavities between the more solid parts, as well as replacing the fruit itself. The densest and most salient part now is the purest pyrites, and was therefore at the time of fossilisation probably the most open part of the fruit or the filling in of cavities. The casts that are found are thus, in the case of hardshelled fruits, more often casts of the space between the outer ligneous shell and the kernel, than of either the kernel or the shell itself. In the case, for instance, of an almon l, we should have most frequently a smooth cast of the inside of the shell, but in perfect fruits the pitted exterior would be preserved, and in fruits partially dissolved the wrinkled kernel would show. In fruits with septa the variety of aspect presented in different stages of preservation is very great, and has doubtless led to the same species being catalogued under several names. The so-called Sequoia or Petrophiloides of Herne Bay is another instance, for the filling-in between the open scales of the cone was thought by Bowerbank to represent confluent scales inclosing cells, the supposed cells being really the cavities left by the true scales which have decayed away, while the infiltrated pyrites has enveloped the seeds which lay under them.

On Monday we took the 8 a.m. train to Herne Bay and searched at Swalecliffe for cones. At Whitstable we set sail in an oyster-boat for Shellness, but some delay occurred in getting it off the ground; the wind dropped in the meantime, and we had to row. Shellness 